\title{
Assessing the probability of crown fire initiation based on fire danger indices
}

\author{
by Miguel G. Cruz ${ }^{1}$, Martin E. Alexander ${ }^{2}$ and Ronald H. Wakimoto ${ }^{3}$
}

The initiation of crown fires in conifer stands was modelled through logistic regression analysis by considering as independent variables a basic physical descriptor of the fuel complex structure and selected components of the Canadian Forest Fire Weather Index (FWI) System. The study was based on a fire behaviour research database consisting of 63 experimental fires covering a relatively wide range of burning conditions and fuel type characteristics. Four models were built with decreasing input needs. Significant predictors of crown fire initiation were: canopy base height, wind speed measured at a height of $10 \mathrm{~m}$ in the open, and four components of the FWI System (i.e., Fine Fuel Moisture Code, Drought Code, Initial Spread Index and Buildup Index). The models predicted correctly the type of fire (i.e., surface or crown) between $90 \%$ and $66 \%$ of the time. The $\mathrm{C}$ index, a statistical measure, varied from 0.94 to 0.71 , revealing good concordance between predicted probabilities and observed events. A comparison between the logistic models and Canadian Forest Fire Behaviour Prediction System models did not show any conclusive differences. The results of a limited evaluation involving two independent experimental fire data sets for distinctly different fuel complexes were encouraging. The logistic models built may have applicability in fire management decision support systems, allowing for the estimation of the probability of crown fire initiation at small and large spatial scales from commonly available fire environment and fire danger rating information. The relationships presented are considered valid for free-burning fires on level terrain in coniferous forests that have reached a pseudo steadystate and are not deemed applicable to dead conifer forests (i.e., insect-killed stands).

Key words: Canadian Forest Fire Danger Rating System, crown fire initiation, fire behaviour, fire danger indices, logistic regression

L'amorce des feux de cime dans les peuplements résineux a été modélisée au moyen de l'analyse d'une régression logistique en considérant comme variables indépendantes un descripteur physique de base de la structure de l'ensemble formant le combustible et certains éléments choisis du Système canadien d'indice météorologique des feux de forêts (IMF). L'étude reposait sur une base de données de recherche sur le comportement du feu constituée de 63 feux expérimentaux rassemblant un assez grand éventail de conditions de brûlage et de caractéristiques du type de combustible. Quatre modèles ont été élaborés en fonction de la décroissance des intrants requis. Les prédicateurs significatifs de l'amorce des feux de cime étaient : la hauteur moyenne des cimes, la vitesse du vent mesurée à une hauteur de $10 \mathrm{~m}$ dans un espace ouvert, et quatre composantes du Système IMF (c'est-à-dire, le code d'humidité des particules fines de combustible, le code de sécheresse, l'indice de répartition initiale et l'indice d'accumulation). Les modèles ont prédit avec exactitude le type de feu (c'est-à-dire, de surface ou de cime) entre $90 \%$ et $66 \%$ du temps. L'indice C, une mesure statistique, a varié entre 0,94 et 0,71 , démontrant une bonne concordance entre les probabilités prédites et les événements observés. Une comparaison entre les modèles logistiques et les modèles du Système canadien de prédiction du comportement des feux de forêts n'a révélé aucune différence significative. Les résultats de l'évaluation restreinte à deux ensembles de données sur des feux expérimentaux indépendants comportant des complexes de combustibles distinctement différents ont été encourageants. L'élaboration de modèles logistiques pourrait avoir une application dans les systèmes d'aide à la prise de décision pour la gestion des feux, permettant un estimé de la probabilité de l'amorce des feux de cime à petites et à grandes échelles dans le cas des situations courantes de feux et en fonction de l'information sur le niveau de danger associé aux feux. Les relations présentées dans cet article sont considérées être valides pour les feux non contrôlés en terrain plat dans des forêts de conifères qui ont atteint un pseudo état d'équilibre et ne sont pas utilisables pour les forêts de conifères mortes (par ex. les peuplements ravagés par des insectes).

Mots-clés: Système canadien de classification des feux de forêt, amorce des feux de cime, indices de danger relié aux feux, régression logistique

\section{Introduction}

The knowledge of fire behaviour is a fundamental component of any fire management system, allowing for the determination of the impact of fire on several ecosystem components, assessment of the effectiveness of fuel treatments, and support for decisionmaking in wildfire suppression planning and in forest management activities that

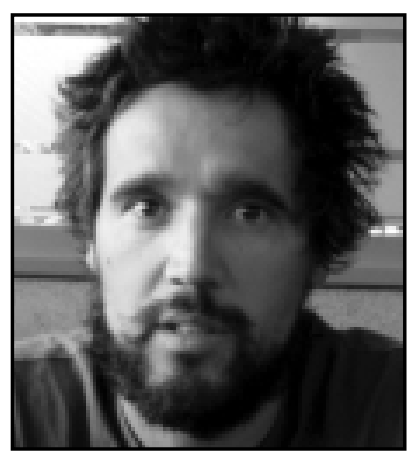

Miguel G. Cruz

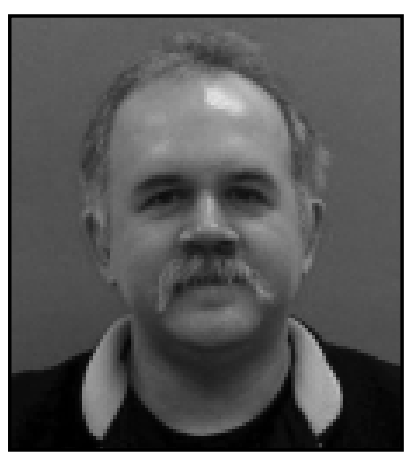

Martin E. Alexander

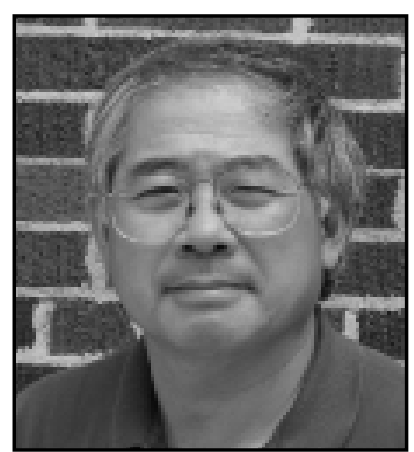

Ronald H. Wakimoto

${ }^{1}$ Associação para o Desenvolvimento da Aerodinâmica Industrial, Apartado 10131, 3031 - 601 Coimbra, Portugal. Presently, Ph.D. Candidate, College of Forestry and Conservation, University of Montana, Missoula, Montana 59812. E-mail: miguel.gomesdacruz@ umontana.edu

${ }^{2}$ Senior Fire Behaviour Research Officer, Natural Resources Canada, Canadian Forest Service, Northern Forestry Centre 5320-122 Street Edmonton, Alberta T6H 3S5. E-mail: malexand@ nrcan.gc.ca

${ }^{3}$ Professor, College of Forestry and Conservation, University of Montana, Missoula, Montana 59812. E-mail: wakimoto@ forestry.umt.edu 
require the use of fire as a tool (Barrows 1968, Countryman 1972). Models for predicting wildland fire behaviour are commonly used operationally by land management agencies in North America (Pyne et al. 1996). Wildland fire research has produced models that enable important fire characteristics to be predicted within acceptable precision for most current field applications. Nevertheless, our fire behaviour "dictionary of ignorance" is still broad (Saveland and Thomas 1998), and a complete fundamental description of a fire front and its impacts on ecosystem components is still largely lacking.

Crown fire initiation has been one aspect of fire behaviour where the current state of knowledge has been limited. From a fire management perspective, knowledge of the onset of crowning is of critical importance from a safety and tactical standpoint, yet few research attempts have been directed at explaining and/or developing models to predict this feature of wildland fire behaviour (Van Wagner 1977a, Xanthopoulos 1990, Alexander 1998, Cruz 1999). This lack of attention probably can be explained by (1) the unknowns in fundamental combustion and heat transfer theory in wildland fuels, (2) the difficulty in replicating such phenomena in a laboratory setting, and (3) the difficulty of instrumenting outdoor high-intensity experimental fires in order to quantitatively describe the influence of relevant variables, important physical processes, and their outcomes.

In Canada, operational fire behaviour prediction currently relies primarily on the Canadian Forest Fire Behaviour Prediction (FBP) System (Forestry Canada Fire Danger Group 1992, Taylor et al. 1997) a subsystem of the Canadian Forest Fire Danger Rating System (CFFDRS) (Stocks et al. 1989). This empirically based system relies in part on statistical relationships between fire weather and fire danger indices of the Canadian Forest Fire Weather Index (FWI) System ${ }^{4}$, the other major subsystem of the CFFDRS, and fire behaviour data garnered from experimental fires and wildfires in specific fuel types (Alexander and Quintilio 1990, McAlpine et al. 1990, Van Wagner 1998).

In the FBP System, crown fire initiation is estimated through the use of the Van Wagner (1977a) crown fire initiation model, which takes into account foliar moisture content and the height to live crown base as a means of defining the energy requirements for canopy ignition and the corresponding surface fire intensity (Byram 1959) as a measure of the heat source. Van Wagner's (1977a) heat balance physical/empirical formulation to define the onset of crowning encompasses relationships from existing theory and experimental outdoor crown fires. Although this model has been embraced by many members of the wildland fire research community in North America (e.g., Bessie and Johnson 1995, Agee 1996, Scott 1998, Graham et al.

\footnotetext{
${ }^{4}$ The FWI System consists of six relative fire danger indices each of which is designed to represent some aspect of fire behaviour (Van Wagner 1987). The Fine Fuel Moisture Code (FFMC) is a numerical rating of the moisture content of litter and other cured fine fuels. The Duff Moisture Code (DMC) is a numerical rating of the average moisture content of loosely compacted organic layers of moderate depth. The Drought Code (DC) is a numerical rating of average moisture content of deep, compacted, organic layers. The Initial Spread Index (ISI) is a numerical rating of the effect of wind and FFMC on rate of spread without the influence of variable quantities of fuel. The Buildup Index (BUI) is a numerical rating of the total amount of fuel available for combustion that combines DMC and DC. The Fire Weather Index (FWI) itself is a numerical rating of fire intensity that combines ISI and BUI.
}

1999), and currently integrates various types of decision aids and decision-support systems for fire management (e.g., Alexander 1988, Forestry Canada Fire Danger Group 1992, Finney 1998, Scott and Reinhardt 2001), it has never been subjected to a formal model evaluation. It possesses several theoretical and practical limitations, namely: (1) its heat of ignition formulation assumes that all the moisture must be driven off before ignition (Xanthopoulos 1990, Alexander 1998), whereas the occurrence of simultaneous drying and pyrolysis (Saastamoinen and Richard 1996) is expected under high energy fluxes such as the ones verified at the onset of crowning; (2) the proportionality constant has been assumed to be universal, although recent research (Alexander 1998) indicates that it is not the case-it is expected that it is dependent on combustion characteristics as determined by surface fuel bed structural properties and fuel moisture dynamics (Cruz 1999); (3) the model is based solely on convective theory, whereas the radiative component might predominate in some burning conditions; (4) the use of Byram's (1959) fire intensity variable requires the estimation of rate of fire spread and fuel consumption from other models, inducing an error propagation problem and increasing the uncertainty of the model system.

The objective of this study was to develop a model to predict the probability of crown fire initiation following the modeling approach similar to that used in the development of the FBP System and other additions of the CFFDRS (Lawson and Dalrymple 1996, Lawson et al. 1997).

It is worth acknowledging that this is not the first attempt to devise a scheme for judging crown fire potential using components of the FWI System (e.g., Lawson 1973, BCMF 1983), other than using specified ISI or FWI values as crown fire thresholds (Alexander and De Groot 1988, Alexander and Lanoville 1989, Lawson et al. 1985). Van Wagner (1974b) developed a special index called the Crown Spread Index (CSI) that was obtained simply by multiplying the ISI value by a Crown Spread Factor (CSF), which was in turn based on a particular season trend in foliar moisture content. The CSF varied from 1.0 to 2.2 and was linked to calendar data for operational ease of use. Crown fires in pine stands, for example, were expected to occur when the CSI exceeded 30. Fuglem and Murphy (1980) constructed graphs linking the standard FWI component-fire intensity relationship found in the FWI System (Van Wagner 1974a, 1987) to Van Wagner's (1977a) criteria for crown fire initiation as dictated by foliar moisture content and live crown base height. Level terrain was assumed in both of these schemes. For whatever reason, neither of these decision aids was ever widely applied.

\section{Methods}

The approach used in this study relies in large part on an extensive, experimental fire behaviour database for natural conifer forest stands. The compiled database consists of 63 observations involving both surface fires and crown fires set for the purpose of studying fire behaviour in relation to the prevailing fuel and weather conditions. The fact that the data have been obtained from outdoor experimental fires implies that there is a high degree of reliability in the documentation of the fire behaviour characteristics and attendant burning conditions. No data from wildfire case studies (Alexander and Lanoville 1987) were used, mainly because they do not provide sufficiently precise information on the fuel complex characteristics and fire 
environment conditions at the time of transition from surface to crown fire spread. The compiled database used in the present study constitutes a subset of that used in the development of the FBP System (Forestry Canada Fire Danger Group 1992). The experimental fire data is thus based on studies carried out in Canada encompassing several different forest stand types and a wide range of fuel complex structures (Van Wagner 1968, 1977a; Lawson 1972; Kiil 1975; Quintilio et al. 1977; Newstead and Alexander 1983; Stocks 1987a, 1989; Weber et al. 1987). A detailed description of the database is given elsewhere (Cruz 1999). Table 1 summarizes basic descriptive statistics of the independent variables selected for analysis. Foliar moisture content, canopy base height, and wind speed are three fire environment variables that theoretically are major factors controlling the onset of crowning and have already been used in modeling this phenomenon (Van Wagner 1977a, Xanthopoulos 1990, Alexander 1998; Cruz et al. 2002). The range and deviation around the mean for these variables suggest a balanced distribution suitable for the statistical analysis to be pursued in the present study. The FWI System fuel moisture codes and fire behaviour indices associated with the experimental fires cover a relatively wide range of conditions under which crown fire initiation is known to occur.

Given the dichotomous nature of the event under study (i.e., occurrence or not of crowning), a logistic regression approach allowing the estimation of the probability of an event occurring from a combination of fire environmental factors is appropriate. Multiple logistic regression models were fitted relying on SPSS 8.0 statistical package (Norusis 1997). The multiple logistic regression model has the following form (from Hosmer and Lemeshow 2000):

$$
P\left(y_{i}=1\right)=\frac{e^{g(x)}}{1+e^{g(x)}}
$$

being the logit given by the equation:

$$
g(x)=\beta_{0}+\beta_{1} x_{1}+\beta_{2} x_{2}+\ldots+\beta_{i} x_{i}
$$

where, $P\left(y_{i}=1\right)$ is the probability of crown fire occurrence, $x_{i}$ are the independent variables, and $\beta_{i}$ are the coefficients estimated through the maximum likelihood method, which will produce coefficients that maximize the probability density as a function of the original set of data. A decision criterion of 0.5 as the threshold of crown fire initiation was assumed. This cutoff value has been commonly used to discriminate the continuous model response in the interval between 0.0 and 1.0 (e.g., Wilson and Ferguson 1986, Ryan and Reinhardt 1988, Wilson 1988, Borchert et al. 2002).

Model fit was assessed through the Nagelkerke (1991) $\mathrm{R}^{2}$ value and the C index (Hanley and McNeil 1982, Regelbrugge and Conard 1993). The Nagelkerke $\mathrm{R}^{2}$ attempts to quantify the proportion of explained variation in the logistic regression model. It is a redefinition of the conventional coefficient of determination (Cox and Snell 1989) so that a maximum value of 1.0 is attained when all observations are correctly predicted. The $\mathrm{C}$ index, which ranges from 0.5 (no discrimination) to 1.0, analyzes model fit through the relation between the predicted probabilities and the observed events. It is

\begin{tabular}{|c|c|c|c|c|}
\hline \multicolumn{5}{|c|}{$\begin{array}{l}\text { Table 1. Basic descriptive statistics of independent variables contained } \\
\text { in the data set used in the logistic model development }(n=63)\end{array}$} \\
\hline Independent variables & Minimum & Maximum & Mean & St. Dev. \\
\hline Foliar moisture content $(\%)$ & 80 & 135 & 108.1 & 8.3 \\
\hline Canopy base height (m) & 0.4 & 12 & 3.9 & 3.0 \\
\hline $10-\mathrm{m}$ open wind speed $(\mathrm{km} / \mathrm{h})$ & 3 & 29 & 12.6 & 5.5 \\
\hline Fine Fuel Moisture Code (FFMC) & 84.5 & 94.1 & 90.5 & 2.0 \\
\hline Duff Moisture Code (DMC) & 9 & 89 & 41.4 & 17.5 \\
\hline Drought (DC) & 60 & 423 & 193.4 & 86.9 \\
\hline Initial Spread Index (ISI) & 3.2 & 21.5 & 9.2 & 4.0 \\
\hline Buildup Index (BUI) & 13 & 109 & 51.2 & 19.4 \\
\hline Fire Weather Index (FWI) & 6 & 43 & 20.7 & 8.3 \\
\hline Rate of fire spread ( $\mathrm{m} / \mathrm{min})$ & 0.4 & 49.4 & 8.7 & 10.3 \\
\hline Fire Intensity $(\mathrm{kW} / \mathrm{m})$ & 62 & 45200 & 6322 & 9342 \\
\hline
\end{tabular}
equivalent to the area under the "receiver operating charac- teristic" curve (Hanley and McNeil 1982, Saveland and Neuenschwander 1990) for a binary dependent variable, and is independent of the decision criteria (Regelbrugge and Conard 1993). Two independent data set comprising a total of 19 experimental fires in two very diverse fuel complexes were used to evaluate general model performance (Alexander et al. 1991, 2001).

\section{Results}

Given the possible applicability of a crown fire initiation model based on readily available or estimated fire environment variables and FWI System components to support fire management decision-making, four models, LOGIT1 through LOGIT4, were developed, each with decreasing input needs (Table 2). The combination of variables defining the larger model was based on the theoretical weight of the variables on the phenomena under study and an attempt to avoid multicollinearity problems. The probability level used for testing the significance of the various parameters as determined by the maximum likelihood method was set at $95 \%$. The maximum likelihood theory applies strictly to large samples (Smith 1969) which limits the analysis of the statistical results reported in Table 2. All of the variables but the DC in LOGIT4 were significant predictors of crown fire initiation.

All the models in Table 2 have a significant reduction in the -2 Log Likelihood (-2LL) against the initial log likelihood function. Overall, model fit decreases from LOGIT1 to LOGIT4 as seen by the increase in the -2LL and the reduction in the Nagelkerke $\mathrm{R}^{2}$ statistic. This particular $\mathrm{R}^{2}$ measure should be interpreted with care, as it is not comparable to the $\mathrm{R}^{2}$ statistic computed in least squares regression. The $\mathrm{R}^{2}$ measure proposed for logistic regression models relies on comparisons between the fitted model and a no data or intercept only model, rather than comparing model predictions with observed values (Hosmer and Lemeshow 2000). These measures are better used for model comparison purposes. Overall, LOGIT1 model correctly predicted $90 \%$ of the fires in the data set. The remaining models did a poorer job of correctly predicting the type of fire in the database. LOGIT4 had the least discriminating power, correctly predicting $74 \%$ of the surface fires and $58 \%$ of the crown fires (Table 2). The computed $\mathrm{C}$ index (Table 2) varied from 0.94 in LOGIT1 to 0.71 in LOGIT4.

\section{Discussion}

The models contained in Table 2 predict the probability of the onset of crowning from logistic regression analysis of the experimental fire data used in the development of several of 


\begin{tabular}{|c|c|c|c|c|c|}
\hline \multirow[b]{2}{*}{ Item } & & \multicolumn{4}{|c|}{ Models } \\
\hline & & LOGIT1 & LOGIT2 & LOGIT3 & LOGIT4 \\
\hline \multirow{6}{*}{$\begin{array}{l}\text { Parameter } \\
\text { values }^{\mathrm{a}}\end{array}$} & Constant & $-66.620(25.93)^{*}$ & $-5.005(1.62)^{* *}$ & $-5.123(1.70)^{* *}$ & $-2.357(0.98)^{*}$ \\
\hline & $\mathrm{CBH}$ & $-0.993(0.31)^{* *}$ & $-0.862(0.24)^{* *}$ & $-1.039(0.62)^{* *}$ & \\
\hline & $\mathrm{U}_{10}$ & $0.568(0.18)^{* * *}$ & & & \\
\hline & FFMC & $0.671(0.29)^{*}$ & & & \\
\hline & $\mathrm{DC}$ & $0.018(0.007)^{* *}$ & $0.014(0.005)^{* * *}$ & & $0.002(0.003)$ \\
\hline & ISI & & $0.672(0.19)^{* *}$ & $0.615(0.18)^{* *}$ & $0.232(0.08)^{* *}$ \\
\hline \multirow{4}{*}{ Model fit } & BUI & & & $0.079(0.03)^{* *}$ & \\
\hline & $-2 \mathrm{LL}$ & 39.16 & 46.22 & 46.21 & 87.53 \\
\hline & Nag. $R^{2}$ & 0.71 & 0.64 & 0.64 & 0.19 \\
\hline & $\mathrm{C}$ index & 0.94 & 0.92 & 0.92 & 0.71 \\
\hline \multirow[t]{2}{*}{ Correctly predicted $(\%)$} & Surface (specificity) & 90 & 80 & 83.3 & 74.3 \\
\hline & Crown (sensitivity) & 91 & 88 & 85 & 58.3 \\
\hline
\end{tabular}

Note: $\mathrm{CBH}$ - canopy base height $(\mathrm{m}) ; \mathrm{U}_{10}-10-\mathrm{m}$ open wind speed (km/h); FFMC - Fine Fuel Moisture Code; DC - Drought Code; ISI - Initial Spread Index; BUI - Buildup Index; -2LL - $-2 \times \log$ likelihood; Nag. $\mathrm{R}^{2}-$ Nagelkerke $\mathrm{R}^{2} ; *$ - significant at $\alpha=0.05$; ** - significant at $\alpha=0.01$ (based on Wald $\chi^{2}$ test).

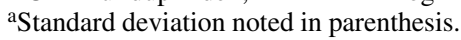

the standing timber fuel type models found in the FBP System. Analysis of the behaviour of these newly developed models should take into account the fact that the models reflect the characteristics of the data set.

All the independent variables included in the models have a direct effect in determining crown fire initiation or are surrogates of fire environment factors that directly influence the potential for crowning. Canopy base height, for example, defines the vertical stratification of the fuel complex and influences the amount of energy that is dissipated within the convection column above a spreading surface fire until such time as the canopy fuels become susceptible to combustion and vertical fire growth. Wind directly affects fire behaviour through the increase in the rate of fire spread and in turn the heat energy released, and consequently the upward heat flux.

The FFMC, DC and BUI components of the FWI System are surrogates for the amount of fuels of different types and sizes available for consumption in the flaming stage of combustion. Neither the DMC nor foliar moisture content was found to be significant in any model formulation. This non-significant effect of the DMC was unexpected because on theoretical grounds the fuel layer it is designed to represent (Van Wagner 1987) is presumed to have a stronger impact than the deep duff layer that the DC characterizes. The BUI, which in the FBP System is indicative of the total amount of fuel available for combustion, was in general, inferior to the DC in explaining this aspect of fire potential.

The non-significance of foliar moisture content might be explained by the fact that some of the foliar moisture content values in the data set are not the result of direct sampling but rather estimates from the FBP System sub-model (Forestry Canada Fire Danger Group 1992) for predicting foliar moisture content from geographical location (latitude/longitude), calendar date and elevation (e.g., Call and Albini 1997) or by other means (e.g., Van Wagner 1993), yielding average values and perhaps masking the effect of this variable. It should be noted that both theory (Van Wagner 1977a, de Mestre et al. 1989) and laboratory studies (e.g., Van Wagner 1967a, 1967b; Xanthopoulos and Wakimoto 1993) indicate a strong effect of foliar moisture content on crown fire initiation (Van Wagner 1998). Nevertheless the effect of live fuels moisture content on fire behaviour is not well understood (Weise et al. 1998) and laboratory studies have not been able to replicate the true thermal environment that characterize high-intensity surface fires, namely the heat fluxes and fluid velocities.

The decision criterion for crowning activity was initially chosen as 0.5 , the midpoint of the probability range. Subsequent analysis of the models sensitivity and specificity variation (Hosmer and Lemeshow 2000) showed that this cutoff point maximizes both parameters (Table 2), and consequently it was considered the optimal threshold value by which to discriminate model predictions within the present data set (i.e., the type of fire-surface or crown).

Canopy base height and the 10-m open wind speed were the independent variables that most strongly influenced the initiation of crowning. Model LOGIT4 being dependent on just the ISI and DC is more prone to erroneous results as these two variables cannot encompass all the possible factors and interactions determining the onset of crowning. The marginal results obtained by LOGIT4 demonstrate the importance of including information on fuel complex characteristics when attempting to predict the onset of crowning. The exclusion of canopy base height as an input variable in the model reduced the Nagelkerke $\mathrm{R}^{2}$ statistic to 0.19 , and the percentage of overall correctly predicted cases to $66 \%$ (Table 2 ).

Model evaluation should be a component of the development process leading to a better understanding of model behaviour and an increase in its credibility. The logistic models (Table 2) were evaluated by comparing their output with other predictive models and against two independent experimental fire data sets. The two independent data sets used for model evaluation were the Porter Lake experimental burning project (Alexander et al. 1991) and the International Crown Fire Modeling Experiment (Alexander et al. 2001). The Porter Lake data set comprises eight experimental fires in a black spruce-lichen woodland fuel complex (Alexander and Lanoville 1989) and the International Crown Fire Modeling Experiment (ICFME) data set includes 11 experimental fire observations in a mature jack pine stand possessing a substantial black spruce understory.

Comparison of model behaviour with other models describing the same event provides an understanding of possible 


\begin{tabular}{|c|c|c|c|c|}
\hline \multirow[b]{2}{*}{ Model } & \multicolumn{4}{|c|}{ Canopy base height (m) } \\
\hline & 3 & 5 & 7 & 9 \\
\hline FBP System C-6 & $0.22 / 0.51 / 0.75$ & $\begin{array}{c}\text { Crown } \mathrm{F} \\
0.00 / 0.21 / 0.60 \\
\text { Probabilit }\end{array}$ & $\begin{array}{l}d(\mathrm{CFB}) \\
0.00 / 0.00 / 0.28 \\
\text { initiation }\end{array}$ & $0.00 / 0.00 / 0.00$ \\
\hline LOGIT1 & $0.20 / 0.81 / 0.99$ & $0.03 / 0.37 / 0.91$ & $0.00 / 0.07 / 0.58$ & $0.00 / 0.01 / 0.16$ \\
\hline LOGIT2 & $0.55 / 0.84 / 0.97$ & $0.18 / 0.49 / 0.86$ & $0.04 / 0.15 / 0.53$ & $0.01 / 0.03 / 0.17$ \\
\hline LOGIT3 & $0.87 / 0.96 / 0.99$ & $0.47 / 0.77 / 0.95$ & $0.10 / 0.30 / 0.70$ & $0.01 / 0.05 / 0.23$ \\
\hline LOGIT4 & $0.43 / 0.55 / 0.70$ & $0.43 / 0.55 / 0.70$ & $0.43 / 0.55 / 0.70$ & $0.43 / 0.55 / 0.70$ \\
\hline
\end{tabular}

Note: CFB: $<0.1$ - surface fire; $0.1-0.89$ - intermittent crown fire; $>0.9$ continuous crown fire. The surface fire/crown fire transition cutoff value for the logistic models is assumed to be 0.5 .

${ }^{a}$ The other defined fuel, fire weather and fire danger conditions were: foliar moisture content $-100 \%$, air temperature $-24.4^{\circ} \mathrm{C}$, relative humidity $26 \%$, days since rain - 9, FFMC - 92.2, DMC - 64, DC - 190, and BUI - 70 (Alexander 1998).

Table 4. Crown fire initiation predictions for the Canadian Forest Fire Behaviour Prediction (FBP) System conifer fuel types with fixed canopy base heights $(\mathrm{CBH})$ and the logistic models developed in the present study at three different $10-\mathrm{m}$ open wind speed levels (i.e., $5 / 10 / 15 \mathrm{~km} / \mathrm{h})^{\mathrm{a}}$

\begin{tabular}{|c|c|c|c|c|c|c|}
\hline Model & $\begin{array}{c}\mathrm{C}-1 \\
(\mathrm{CBH}=2 \mathrm{~m})\end{array}$ & $\begin{array}{c}\mathrm{C}-2 \\
(\mathrm{CBH}=3 \mathrm{~m})\end{array}$ & $\begin{array}{c}\mathrm{C}-3 \\
(\mathrm{CBH}=8 \mathrm{~m})\end{array}$ & $\begin{array}{c}\mathrm{C}-4 \\
(\mathrm{CBH}=4 \mathrm{~m})\end{array}$ & $\begin{array}{c}\mathrm{C}-5 \\
(\mathrm{CBH}=18 \mathrm{~m})\end{array}$ & $\begin{array}{c}\mathrm{C}-7 \\
(\mathrm{CBH}=10 \mathrm{~m})\end{array}$ \\
\hline FBP System & $0.08 / 0.38 / 0.72$ & $0.86 / 0.94 / 0.98$ & $\begin{array}{r}\text { Crown Frac } \\
0.00 / 0.00 / 0.49 \\
\text { Probability of }\end{array}$ & $\begin{array}{l}\text { 3urned (CFB) } \\
0.83 / 0.93 / 0.98 \\
\text { n fire initiation }\end{array}$ & $0.00 / 0.00 / 0.00$ & $0.00 / 0.00 / 0.00$ \\
\hline LOGIT1 & $0.40 / 0.92 / 0.99$ & $0.20 / 0.81 / 0.99$ & $0.00 / 0.03 / 0.33$ & $0.08 / 0.61 / 0.96$ & $0.00 / 0.00 / 0.00$ & $0.00 / 0.00 / 0.06$ \\
\hline LOGIT2 & $0.73 / 0.92 / 0.99$ & $0.54 / 0.84 / 0.97$ & $0.02 / 0.06 / 0.31$ & $0.33 / 0.68 / 0.93$ & $0.00 / 0.00 / 0.00$ & $0.00 / 0.01 / 0.07$ \\
\hline LOGIT3 & $0.95 / 0.99 / 1.00$ & $0.87 / 0.96 / 0.99$ & $0.04 / 0.12 / 0.44$ & $0.70 / 0.90 / 0.98$ & $0.00 / 0.00 / 0.00$ & $0.00 / 0.02 / 0.09$ \\
\hline LOGIT4 & $0.42 / 0.55 / 0.70$ & $0.42 / 0.55 / 0.70$ & $0.42 / 0.55 / 0.70$ & $0.42 / 0.55 / 0.70$ & $0.42 / 0.55 / 0.70$ & $0.42 / 0.55 / 0.70$ \\
\hline
\end{tabular}

Note: CFB: $<0.1$ - surface fire; $0.1-0.89$ - intermittent crown fire; $>0.9$ continuous crown fire. The surface fire/crown fire transition cutoff value for the logistic models is assumed to be 0.5 .

${ }^{\text {a }}$ The other defined fuel, fire weather and fire danger conditions were: foliar moisture content $-100 \%$, air temperature $-24.4^{\circ} \mathrm{C}$, relative humidity $-26 \%$, days since rain - 9, FFMC - 92.2, DMC - 64, DC - 190, and BUI - 70 (Alexander 1998).

model deficiencies and their limits of applicability. A limited comparison of the models developed in the present study with the fuel type specific models found in the FBP System models was therefore undertaken (Table 3 and 4 ) for several of the standing timber fuel types, namely C-1 (spruce-lichen woodland), C-2 (boreal spruce), C-3 (mature jack or lodgepole pine), C-4 (immature jack or lodgepole pine), C-5 (red and white pine), C-6 (conifer plantation), and C-7 (ponderosa pine/Douglas-fir). Detailed descriptions of these fuel types and their specific sub-models can be found in the technical report on the FBP System (Forestry Canada Fire Danger Group 1992) and photographic examples can be found in De Groot (1993) and Taylor et al. (1997). Given that the various model inputs differ, model comparison should be based on well-documented burning conditions where all relevant input variables were measured. For present purposes then, the model comparison was done according to the burning conditions that prevailed during experimental crown fire $\mathrm{R} 1$ in a red pine plantation at the Petawawa Forest Experiment Station in eastern Ontario as described by Van Wagner (1964), with variable 10-m open wind speeds (i.e., 5, 10 and $15 \mathrm{~km} / \mathrm{h}$ ). In the FBP System a nominal canopy base height is assigned to each fuel type judged susceptible to crowning. There is one exception. Surface and crown fire behaviour in FBP System fuel type C-6 is modeled in a slightly distinct way, by incorporating two equations, one for surface spread and another for crown spread (Forestry Canada Fire Danger Group 1992). This allows for variable canopy base heights. Thus, the FBP System C-6 model was compared against the logistic models on the basis of several CBH levels (i.e., 3, 5, 7 and $9 \mathrm{~m}$, with $7 \mathrm{~m}$ being the standard default value).
The evaluation results for the FBP System fuel types were expressed in the form of the crown fraction burned (CFB) ${ }^{5}$. $\mathrm{A} C \mathrm{CFB}$ of less than 0.1 is indicative of a surface fire whereas intermittent crown fires have a CFB between 0.1 and 0.89 and continuous crown fires have a CFB greater than 0.9 (Forestry Canada Fire Danger Group 1992).

There are not necessarily any conclusive trends or differences between the two modeling approaches (Table 3 ). The FBP System models show a large variability relative to the likelihood of crowning between the various fuel types, being that the system is more likely to predict the initiation of crowning in fuel types C-2 and C-4 fuel types than in the other fuel types, fuel types $\mathrm{C}-5$ and $\mathrm{C}-7$ with relatively high $\mathrm{CBHs}$ and in turn low susceptibility to crowning. Due to their different forms, it is difficult to compare directly the outputs from the logistic models with the FBP System models. Examination of Table 4 indicates that for fuel type C- 1 and C-3, the FBP System predictions are more conservative than those obtained from the logistic models. The opposite situation occurs for fuel types C-2 and C-4, with the logistic models producing the most conservative predictions.

The logistic models show distinct results. LOGIT1 and LOGIT2 show very similar behaviour and within the logistic models, they produce the most conservative estimates. The integration of wind speed and FFMC into the ISI parameter (for LOGIT1

\footnotetext{
${ }^{5} \mathrm{CFB}$ is a measure of the degree of potential crown fuel consumption expressed as a proportion of the total number of tree crowns and as such constitutes an indication of the probable type of fire activity to be experienced over a burned area for fuel types that are susceptible to crowning.
} 
to LOGIT2) did not cause major changes in model results. LOGIT3 is the least conservative of the logistic models, predicting the initiation of crown fire under fire environment conditions that intuitively would not suggest its occurrence. LOGIT4 results are in-between the other three logistic models, yielding reasonable behaviour, although there is the uncertainty about not accounting for the vertical stratification of the fuel complex. Several studies have developed equations to predict canopy base height from commonly available stand characteristics (e.g., Cole and Jensen 1982, McAlpine and Hobbs 1994, Cruz et al. 2003a). In the logistic models presented here, the canopy base height is input-variable. This is in contrast to the FBP System where, except for fuel type C-6, it is, strictly speaking, a fixed value for a given fuel type. Users may still want to select a default value after some trial and error based on local experience, including examination of past incidents.

One limitation of the logistic models is that they do not take into account the effect of any other fuel complex characteristic other than canopy base height in the process of defining the likelihood of crown fire initiation. Canopy bulk density is also an important variable in determining crown fire development (Van Wagner 1977). Agee (1996), for example, has suggested that a minimum canopy bulk density of $0.1 \mathrm{~kg} / \mathrm{m}^{3}$ is needed in order to ensure active crown fire spread in a horizontal dimension. In the models presented here, it is assumed that the canopy bulk density is sufficient to support the onset of crowning in the vertical dimension, although it is acknowledged that the critical threshold value is not presently known.

The results of logistic models applied to the two independent experimental fire data sets are presented in Table 5. The Porter Lake experimental fires had an average $\mathrm{CBH}$ of 0.8 $\mathrm{m}$ whereas the ICFME fires exhibited an average CBH of $\sim 6.6$ $\mathrm{m}$ based on the height of the base of the live jack pine and black spruce overstory. The logistic models correctly predicted or classified all the crown fires in the Porter Lake data set. For the ICFME data set, the logistic models correctly classified most of the 11 experimental fire observations as crown fires. Two of the ICFME crown fires were classified as surface fires by all four LOGIT models. One of these two fires did initially advance following ignition as a "wall of flame" via torching and sporadic crowning; this initial burst of high-intensity fire behaviour could have been due in part to edge effects. However, the ambient winds decreased after about five minutes at which time the fire had advanced roughly half way across the experimental plot (i.e., $\sim 75 \mathrm{~m}$ ). When the winds did finally pick up, the fire had turned into a low-intensity surface fire, at which time crowning activity did not become re-established. In other words, it is likely that this experimental fire was just at the point of surface-crown fire transition for the prevailing fuel and weather condition. It is interesting that the logistic models were able to discriminate this particular experimental fire, as all the other fires behaved as truly active or fully developed crown fires. The other experimental fire that was predicted to spread as a surface fire featured a short, dense black spruce understory that acted as an effective ladder or bridge fuel and is not accounted for in the $\mathrm{CBH}$, which is based on the jack pine and the taller black spruce overstory stems.

\section{Conclusions}

The models developed in the present study offer a possible alternative means of estimating the onset of crowning with-
Table 5. Results of evaluation of the logistic models developed in the present study against two independent experimental fire data sets - the Porter Lake experimental burning project (Alexander et al. 1991) and the International Crown Fire Modeling Experiment (ICFME) (Alexander et al. 2001)

\begin{tabular}{llcc}
\hline Model & Type of fire & $\begin{array}{c}\text { Porter Lake } \\
\text { (Pred./Obs.) }\end{array}$ & $\begin{array}{c}\text { ICFME } \\
\text { (Pred./Obs.) }\end{array}$ \\
\hline LOGIT1 & Surface fires & $0 / 0$ & $1 / 0$ \\
& Crown fires & $8 / 8$ & $10 / 11$ \\
LOGIT2 & Surface fires & $0 / 0$ & $2 / 0$ \\
& Crown fires & $8 / 8$ & $9 / 11$ \\
LOGIT3 & Surface fires & $0 / 0$ & $3 / 0$ \\
& Crown fires & $8 / 8$ & $8 / 11$ \\
LOGIT4 & Surface fires & $0 / 0$ & $2 / 0$ \\
& Crown fires & $8 / 8$ & $9 / 11$ \\
\hline
\end{tabular}

Note: The surface fire/crown fire transition cutoff value for the logistic models is assumed to be 0.5 .

in the context of the CFFDRS, although it is not known if the approach presented in this study is in any way superior to the FBP System. Certainly, one distinct advantage is that the probabilistic outcomes of the logistic models allow users to interpret the results differently from the dichotomous answer regarding the possibility of crown fire initiation provided by the FBP System. Based on user experience with the models in a particular fuel type, threshold scores could be locally defined for the probability of crowning.

Errors associated with the uncertainty in estimating fire environment input variables coupled with the inherent errors in outputs from the fire spread and fuel consumption models used in estimating fire intensity can lead to combined errors of up to an order of magnitude. Thus, exclusion of fire behaviour model outputs, such as rate of spread, fuel consumption or fire intensity as independent variables in the logistic models developed in the present study can be seen as a distinct advantage since the approach eliminates the possibility of error propagation in the process of predicting crown fire initiation. Admittedly, the use of FWI System components can introduce some error into the model system since they are in turn dependent on weather inputs (Turner and Lawson 1978), although at a much smaller scale.

No formal model evaluation procedure, including such components as sensitivity analysis, model soundness, statistical and operational validation was carried out (cf. Cruz et al. $2003 \mathrm{~b}$ ), as this was considered outside the scope of this study. Such evaluation would be required to better understand model behaviour and assess the applicability of the models to fuel complexes distinct from the ones used in model development.

By the very nature of the data used to develop the logistic models described here, the predictions are deemed relevant solely to live, conifer-dominated forests that are susceptible to crowning as opposed to disease or insect-killed stands (Stocks 1987b). Fires are assumed to have reached a "quasi" steadystate spread rate and intensity for the prevailing burning conditions (Catchpole 2002). Furthermore, model predictions are valid only for level terrain and no allowance is made for the effect of slope steepness (Van Wagner 1977b) in determining crown fire initiation.

\section{Acknowledgements}

The authors would like to thank the Canadian Forest Service for making available its experimental fire behaviour database for the present study and its staff for the collection 
and safekeeping of such unique data through the years. Thanks also to Dick Lane from the University of Montana for the statistical advice. This paper also benefited from many useful suggestions of two anonymous reviewers.

\section{References}

Agee, J.K. 1996. The influence of forest structure on fire behaviour In Proceedings of the $17^{\text {th }}$ Annual Forest Vegetation Management Conference, Redding, California, January 16-18, 1996. pp. 52-67. Alexander, M.E. 1988. Help in making crown hazard assessments. In Protecting People and Homes from Wildfire in the Interior West: Proceedings of Symposium and Workshop. pp. 147-156. USDA Forest Service, Intermountain Forest and Range Experiment Station, Ogden UT. General Technical Report INT-251.

Alexander, M.E. 1998. Crown fire thresholds in exotic pine plantations of Australasia. Australian National University, Canberra, Australia. Ph.D. Thesis. 228 p.

Alexander, M.E. and W.J. De Groot. 1988. Fire behaviour in jack pine stands as related to the Canadian Forest Fire Weather Index (FWI) System. Canadian Forestry Service, Northern Forestry Centre, Edmonton, AB. Poster with text.

Alexander, M.E. and R.A. Lanoville. 1987. Wildfires as a source of fire behaviour data: a case study from Northwest Territories, Canada. In Conference Papers, Ninth Conference on Fire and Forest Meteorology. pp. 86-93. American Meteorological Society, Boston, MA.

Alexander, M.E. and R.A. Lanoville. 1989. Predicting fire behaviour in the black spruce-lichen woodland fuel type of western and northern Canada. Forestry Canada, Northern Forestry Centre, Edmonton, $\mathrm{AB}$, and Government of Northwest Territories, Department of Renewable Resources, Territorial Forest Fire Centre, Fort Smith, NT. Poster with text.

Alexander, M.E. and D. Quintilio. 1990. Perspectives on experimental fires in Canadian forestry research. Math. Comput. Modeling 13(12): 17-26.

Alexander, M.E., B.J. Stocks, B.M. Wotton and R.A. Lanoville. 2001. Tracking the spread and intensity of crown fires. Initial Attack 2001(Fall): 8-11.

Alexander, M.E., B.J. Stocks and B.D. Lawson. 1991. Fire behaviour in black spruce-lichen woodland: the Porter Lake project. Forestry Canada, Northern Forestry Centre, Edmonton, AB. Information Report NOR-X-310. 44 p.

Barrows, J.S. 1968. Intelligence systems for forest fire control. In Proceedings of the Sixth World Forestry Congress, Volume 2. pp. 1934-1940. Spanish Ministry of Agriculture, Madrid, Spain.

Bessie, W.C. and E.A. Johnson. 1995. The relative importance of fuels and weather on fire behaviour in subalpine forests. Ecology 76: 747-762. BCMF. 1983. Fire weather indices, decision aids for forest operation in British Columbia. British Columbia Ministry of Forests (BCMF), Protection Branch, Vicotoria, British Columbia. Forest Protection Handbook 12, 57 p.

Borchert, M., D. Schreiner, T. Knowd and T. Plumb. 2002. Predicting postfire survival in coulter pine (Pinus coulteri) and Gray pine (Pinus sabiniana) after wildfire in central California. West. J. Appl. For. 17: 134-138.

Byram, G.M. 1959. Combustion of forest fuels. In K.P. Davis (ed.). Forest Fire: Control and Use. pp. 61-89, 554-555. McGrawHill Book Company, New York.

Call, P.T. and F.A. Albini. 1997. Aerial and surface fuel consumption in crown fires. Int. J. Wildland Fire 7: 259-264.

Catchpole, W.R. 2002. Fire properties and burn patterns in heterogeneous landscapes. In R.A. Bradstock, J.E. Williams and M.A. Gill (eds.). Flammable Australia: The Fire Regimes and Biodiversity of a Continent. pp. 49-75. Cambridge Univ. Press, Cambridge Cole, D.M. and C.E. Jensen. 1982. Models for describing vertical development of lodgepole pine stands. USDA Forest Service, Intermountain Forest and Range Experiment Station, Ogden, UT. General Technical Report INT-292. 10 p.
Countryman, C.M. 1972. The fire environment concept. USDA Forest Service, Pacific Southwest Forest and Range Experiment Station, Berkeley, CA. 12 p.

Cox, D.R. and E.J. Snell. 1989. The analysis of binary data. $2^{\text {nd }}$ edition. Chapman and Hall, London. 240 p.

Cruz, M.G. 1999. Modeling the initiation and spread of crown fires. University of Montana, Missoula, MT. M.Sc. Thesis. 162 p. Cruz, M.G., M.E. Alexander and R.H. Wakimoto. 2002. Predicting crown fire behaviour to support forest fire management decision-making. In D.X. Viegas (ed.). Forest Fire Research and Wildland Fire Safety: Proceedings of IV International Conference on Forest Fire Research/2002 Wildland Fire Safety Summit. Millpress Sci. Publ., Rotherdam. CD-ROM. 11 p.

Cruz, M.G., M.E. Alexander and R.H. Wakimoto. 2003a. Assessing canopy fuel stratum characteristics in crown fire prone fuel types of western North America. Int. J. Wildland Fire 12: 39-50.

Cruz, M.G., M.E. Alexander and R.H. Wakimoto. 2003b. Definition of a fire behaviour model evaluation protocol: a case study application to crown fire behaviour models. In P.N. Omi and L.A. Joyce (tech. eds.). Fire, Fuel treatments, and Ecological Restoration: Conference Proceedings. pp. 49-67. USDA Forest Service, Rocky Mountain Research Station, Fort Collins, CO. Proceedings RMRS-P-29. (in press).

De Groot, W.J. 1993. Examples of fuel types in the Canadian Forest Fire Behaviour Prediction (FBP) System. Forestry Canada, Northern Forestry Centre, Edmonton, AB. Poster with text.

de Mestre, N.J., E.A. Catchpole, D.H. Anderson and R.C. Rothermel. 1989. Uniform propagation of a planar fire front without wind. Combust. Sci. Tech. 65: 231-244.

Finney, M.A. 1998. FARSITE: Fire area simulator - model development and evaluation. USDA Forest Service, Rocky Mountain Research Station, Ogden, UT. Research Paper RMRS-RP-4. 47 p.

Forestry Canada Fire Danger Group. 1992. Development and structure of the Canadian Forest Fire Behaviour Prediction System. Forestry Canada, Science and Sustainable Development Directorate, Ottawa, ON. Information Report ST-X-3. 65 p.

Fuglem, P.L. and P.J. Murphy. 1980. Foliar moisture content and crown fires in Alberta conifers. Alberta Energy and Natural Resources, Edmonton, AB. ENR Report No. 158. 47 p.

Graham, R.T., A.E. Harvey, T.B. Jain and J.R. Tonn. 1999. The effects of thinning and similar stand treatments on fire behaviour in western forests. USDA Forest Service, Pacific Northwest Research Station, Portland, OR. General Technical Report PNW-GTR-463. $27 \mathrm{p}$.

Hanley, J.A. and B.J. McNeil. 1982. The meaning and use of the area under the receiver operating characteristic (ROC) curve. Radiology 143: 29-36.

Hosmer, D.W. and S. Lemeshow. 2000. Applied logistic regression. $2^{\text {nd }}$ edition. John Wiley \& Sons, New York. 375 p.

Kiil, A.D. 1975. Fire spread in a black spruce stand. Can. For. Serv. Bi-Mon. Res. Notes 31: 2-3.

Lawson, B. D. 1972. Fire spread in lodgepole pine stands. University of Montana, Missoula, MT. M.Sc. Thesis. 119 p.

Lawson, B.D. 1973. Fire behavior in lodgepole pine stands related to the Canadian Fire Weather Index. Canadian Foresty Service, Pacific Forest Research Centre, Victoria, BC. Information Report BC-X-76. 26 p.

Lawson, B.D. and G.N. Dalrymple. 1996. Probabilities of sustained ignition in lodgepole pine, interior Douglas-fir, and white spruce-subalpine fir forest types. Canadian Forest Service, Pacific Forestry Centre, Victoria, BC. FRDA Handbook 12 Supplement 1. $17 \mathrm{p}$.

Lawson, B.D., W.H. Frandsen, B.C. Hawkes and G.N. Dalrymple. 1997. Probability of sustained smouldering ignition for some boreal forest types. Canadian Forest Service, Northern Forestry Centre, Edmonton, AB. Forest Management Note 63.11 p.

Lawson, B.D., B.J. Stocks, M.E. Alexander and C.E. Van Wagner. 1985. A system for predicting fire behaviour in Canadian 
forests. In L.R. Donoghue and R.E. Martin (eds.). Proceedings of Eighth Conference on Fire and Forest Meteorology. pp. 6-16. Society of American Foresters, Bethesda, MD. SAF Publication 85-04.

McAlpine, R.S. and M.W. Hobbs. 1994. Predicting the height to live crown base in plantations of four boreal forest species. Int. J. Wildland Fire 4: 103-106.

McAlpine, R.S., B.J. Stocks, C.E. Van Wagner, B.D. Lawson, M.E. Alexander and T.J. Lynham. 1990. Forest fire behaviour research in Canada. In Proceedings of International Conference on Forest Fire Research, University of Coimbra, Coimbra, Portugal. pp. A.02: $1-12$.

Nagelkerke, N.J.D. 1991. A note on a general definition of the coefficient of determination. Biometrika 78: 691-692.

Newstead, R.G. and M.E. Alexander. 1983. Short-term fire retardant effectiveness in a lowland black spruce fuel complex. Canadian Forestry Service, Northern Forest Research Centre, Edmonton, AB. Forestry Report 28: 3-4.

Norusis, M.J. 1997. SPSS professional statistics. SPSS Inc., Chicago. $376 \mathrm{p}$.

Pyne, S.J., P.L. Andrews and R.D. Laven. 1996. Introduction to wildland fire. $2^{\text {nd }}$ edition. John Wiley \& Sons Inc., New York. 769 p.

Quintilio, D., G.R. Fahnestock and D.E. Dubé. 1977. Fire behaviour in upland jack pine: the Darwin Lake Project. Canadian Forestry Service, Northern Forest Research Centre, Edmonton, AB. Information Report NOR-X-174. 49 p.

Regelbrugge, J.C. and S.G. Conard. 1993. Modeling tree mortality following wildfire in Pinus ponderosa forests in the central Sierra Nevada of California. Int. J. Wildland Fire 3: 139-148.

Ryan, K.C. and E.D. Reinhardt. 1988. Predicting postfire mortality of seven western conifers. Can. J. For. Res. 18: 1291-1297.

Saastamoinen, J. and J.R. Richard. 1996. Simultaneous drying and pyrolysis of solid fuel particles. Combustion and Flame 106: 288-300.

Saveland, J.M. and L.F. Neuenschwander. 1990. A signal detection framework to evaluate models of tree mortality following fire damage. For. Sci. 36: 66-76.

Saveland, J. and D. Thomas (tech. cords.). 1998. Wildland fire research: future search conference. USDA Forest Service, Rocky Mountain Research Station, Fort Collins, CO. Proceedings RMRS-P-1. 48 p. Scott, J.H. 1998. Fuel reduction in residential and scenic forests: a comparison of three treatments in a western Montana ponderosa pine stand. USDA Forest Service, Rocky Mountain Research Station, Ogden, UT. Research Paper RMRS-RP-5. 19 p.

Scott, J.H. and E.D. Reinhardt. 2001. Assessing crown fire potential by linking models of surface and crown fire behaviour. USDA Forest Service, Rocky Mountain Research Station, Fort Collins, CO. Research Paper RMRS-RP-29. 59 p.

Smith, C.A.B. 1969. Biomathematics: the principles of mathematics for students of biological and general science. Volume II. $4^{\text {th }}$ edition. C. Griffin \& Company Ltd., London. 523 p.

Stocks, B.J. 1987a. Fire behaviour in immature jack pine. Can. J. For. Res. 17: 80-86.

Stocks, B.J. 1987b. Fire potential in the spruce-budworm damaged forests of Ontario. For. Chron. 63: 8-14.

Stocks, B.J. 1989. Fire behaviour in mature jack pine. Can. J. For. Res. 19: 783-790.

Stocks, B.J., B.D. Lawson, M.E. Alexander, C.E. Van Wagner, R.S. McAlpine, T.J. Lynham and D.E. Dubé. 1989. The Canadian Forest Fire Danger Rating System: an overview. For. Chron. 65: 450-457.

Taylor, S.W., R.G. Pike and M.E. Alexander. 1997. Field guide to the Canadian Forest Fire Behaviour Prediction (FBP) System. Canadian Forest Service, Northern Forestry Centre, Edmonton, AB. Special Report 11.60 p.
Turner, J.A. and B.D. Lawson. 1978. Weather in the Canadian Forest Fire Danger Rating System: a user guide to national standards and practices. Canadian Forestry Service, Pacific Forest Research Centre, Victoria, BC. Information Report BC-X-177. 40 p.

Van Wagner, C.E. 1964. History of a small crown fire. For. Chron. 40: 202-205, 208-209.

Van Wagner, C.E. 1967a. Flammability of Christmas trees. Rev. edition. Canada Department of Forestry and Rural Development, Forestry Branch, Ottawa, ON. Departmental Publication No. 1034. 27 p.

Van Wagner, C.E. 1967b. Seasonal variation in moisture content of eastern Canadian tree foliage and possible effect on crown fires. Canada Department of Forestry and Rural Development, Forestry Branch, Ottawa, ON. Departmental Publication No. 1204. 15 p.

Van Wagner, C.E. 1968. Fire behaviour mechanisms in a red pine plantation: field and laboratory evidence. Canada Department of Forestry and Rural Development, Forestry Branch, Ottawa, ON. Departmental Publication. 1229. 30 p.

Van Wagner, C.E. 1974a. Structure of the Canadian Forest Fire Weather Index. Canadian Forestry Service, Ottawa, ON. Departmental Publication $1333.44 \mathrm{p}$.

Van Wagner, C.E. 1974b. A spread index for crown fires in spring. Canadian Forestry Service, Petawawa Forest Experiment Station, Chalk River, ON. Information Report PS-X-55. 12 p.

Van Wagner, C.E. 1977a. Conditions for the start and spread of crown fire. Can. J. For. Res. 7: 23-34.

Van Wagner, C.E. 1977b. Effect of slope on fire spread rate. Can. For. Serv. Bi-mon. Res. Notes 33: 7-8.

Van Wagner, C.E. 1987. Development and structure of the Canadian Forest Fire Weather Index System. Canadian Forestry Service, Ottawa, ON. Forestry Technical Report. 35.37 p.

Van Wagner, C.E. 1993. Prediction of crown fire behaviour in two stands of jack pine. Can. J. For. Res. 23: 442-449.

Van Wagner, C.E. 1998. Modeling logic and the Canadian Forest Fire Behaviour Prediction System. For. Chron. 74: 50-52.

Weber, M.G., M. Hummel and C.E. Van Wagner. 1987. Selected parameters of fire behaviour and Pinus banksiana Lamb. regeneration in eastern Ontario. For. Chron. 63: 340-346.

Weise, D. R., R. A. Hartford and L. Mahaffey. 1998. Assessing live fuel moisture for fire management applications. In T.L. Pruden and L.A. Brennan (eds.). Fire in Ecosystem Management: Shifting the Paradigm from Suppression to Prescription. Tall Timbers Fire Ecology Conference Proceedings, No. 20. pp. 49-55. Tall Timbers Research Station, Tallahassee, FL.

Wilson, A.A.G. 1988. Width of firebreak that is necessary to stop grass fires: some field experiments. Can. J. For. Res. 18: 682-687. Wilson, A.A.G. and I.S. Ferguson. 1986. Predicting the probability of house survival during bushfires. J. Environ. Manage. 23: 259-270.

Xanthopoulos, G. 1990. Development of a wildland crown fire initiation model. University of Montana, Missoula, MT. Ph.D. Dissertation. $152 \mathrm{p}$.

Xanthopoulos, G. and R.H. Wakimoto. 1993. A time to ignition - temperature - moisture relationship for branches of three western conifers. Can. J. For. Res. 23: 253-258. 